\title{
Film Reception by Means of New Media or How the Film Escaped from the Cinema
}

\author{
Assistant Professor Gordana Tkalec, Ph.D. \\ Assistant Professor Iva Rosanda Žigo, Ph.D. \\ University North, Department for Journalism
}

Trg dr. Žarka Dolinara

Koprivnica, Croatia

\begin{abstract}
The biggest change in film reception occurred in the moment when the film audience began to watch films over the Internet, or with devices that can connect to it, i.e. computers, laptops and smartphones. The paper redefined notions of contemporary audience and different horizons of expectations, and a new horizon of expectations has been established, and that is the horizon of device expectations. Also, we have redefined the conative function i.e. the empty spaces function, individual and social reception of the film, while the theory of production relations in the case of the production of art has been applied to the film industry. The paper applies to the film received through social networks requirements of all characteristics of new media, which is also a novelty in scientific thinking.
\end{abstract}

Keywords: Reception theory, horizon of expectations, film audience, social networks, information and communication technologies

\section{Introduction}

Motivated by a lack of attention that is given to the systematization of theory postulates of media reception in Croatia and its environment, and consequently with almost the total lack of their implementation, we decided to deal with the issue of the film reception in more detail, at the moment in time when the way in which the film can be accessed in terms of technology significantly changed. This significant change is reflected primarily in the mobile, Internet transmission of films and hence the film 'consumption' gets relocated from the controlled conditions of cinemas and homes and becomes available at any moment. This change is followed by the change of the audience, its characteristics, expectations and requirements that should also be considered from the aspect of the reception theory. As the reception theory has met with different interpretations over the years, we decided to check out contemporary events through the postulates of original theorists in order to find out if they are applicable in the new media challenges as well. We have opted for this approach due to the especially noticeable lack of scientific production in the environment related to the film reception, which is not surprising given that, unfortunately, scientists have transferred dealing with film onto professional levels that, when the film reception is in question, almost exclusively deal with how the audience received a particular film.

On the other hand, the world's scientific journals (mostly American and British) intensively deal with the problems of film, literature and other media's reception, although their systems do not draw a line between scientific and professional approaches, but still this professional approach is at much higher level than the commercially-semi-scientific approach which we are witnesses of in countries of the region. And although it served to us as preliminary research in the form of content analysis, in this paper we will use only small parts of the analysed corpus that can be considered somewhat deficient from the methodological point of view because it is too broad and not fully defined: the study included the search of online content i.e. scientific journals, which are allowed in free access and those that are available to the Croatian academic community in the temporary access (such as a collection of research and academic journals 'Oxford Journals' that was available until December 4, 2016). The main corpus of the paper will consist of the application of the basic concepts of the reception theory of its primary theorists (Jauss, Isser, Mandelkov, Marx and Nauman) to the medium of film, or to the 
reception of the film through the devices connected to the internet, while the paper will also indicate the possible ways of their redefining. A review of the global reception-theoretical production will constitute a smaller part of the paper.

The third motivational aspect is the expected functionality of the initiated researches and scientific work on the definition of legality of media reception shown and customized for the specific medium of film, or in the narrow sense for the film reception by means of information and communication technologies. This paper does not intend in any way to represent a new reception-film manifesto, but rather it tends to 'update' and adapt the existing standpoints to the contemporary film and social changes. The biggest change occurred in the moment when the film audience began to watch films over the Internet, or with devices that can connect to it, i.e. computers, laptops and smartphones. Therefore, this change is necessarily reflected on the film reception as well.

The hypothesis of this paper was that, through the darting changes brought by the advancement of information and communication technologies, which caused a reversal in the understanding and functioning of all forms of human communication, the biggest change was experienced by the audience which represents one of the basic concepts and approaches of the reception theory. The change of such an important factor places the whole reception theory in imbalance and comes to standstill, that is, it also includes the changes of other factors in a greater or lesser extent, and searches for redefining of the theoretical assumptions so that the balance can be established again.

\section{Examples of the Application of Literary Reception Theory to the Film Medium}

As we have said in the introduction, the application of the theory of literary reception to the medium of film is not by any means a new approach. We will show here only a few randomly selected examples from the extensive corpus dealing with similar issues, but they do not deal with the change in the reception influenced by ICT, which we consider our own contribution to science.

In their work, 'Narrative', Thomas Albrecht and Celine Surprenant give a book review by Karl Kroeber ${ }^{1}$ stressing his study as extremely important for the portraying of the novels of the nineteenth century in the films of the twentieth century. 'Kroeber's approach to this topic is a combination of a casual formalist analysis and what might be called reception theories/.../I.../ (in this portion of his demonstration, he makes reference to classical reception theory, for instance to the work of Wolfgang Iser). I.../ Some of these points have been addressed more systematically, more rigorously, and in greater detail by current and past scholarship in narrative theory'.

In her work 'Film Theory', Lisa Trahair 2 also refers to contemporary research of reception theory on examples of actual, empirical viewers of the film with the assumed future, 'secondary' audiences and deferred meanings of the film text. 'In these terms, cinema, like other arts and technologies, is not bound to the predictability of the future (le future) but the unpredictability of l'avenir, the time to come'.

In the work of the same name ('Film Theory') Lisabeth During and Deborah Levitt are doing a review of expert books on film ${ }^{3}$ which recreate the historical approach to the film in very different ways, and in doing so, they move away from the so

\footnotetext{
${ }_{1}^{1}$, Make Believe in Film and Fiction: Visual vs. Verbal Storytelling is a study of considerable value to anyone interested in nineteenthcentury novels, in twentieth-century narrative cinema, and in the question of how novels and films tell stories differently. Kroeber's approach to this topic is a combination of a casual formalist analysis and what might be called reception theories. On the one hand, he discusses and compares passages from well-known European realist novels and sequences from classical Hollywood and postwar European narrative films in order to demonstrate how each constructs a narrative using very distinct techniques (his first chapter, for example, opens by suggestively juxtaposing the ax murder scene from Dostoevsky's Crime and Punishment with the killing of Marion Crane in Alfred Hitchcock's Psycho [1960]). I ... / (in this portion of his demonstration, he makes reference to classical reception theory, for instance to the work of Wolfgang Iser). I.../ Some of these points have been addressed more systematically, more rigorously, and in greater detail by current and past scholarship in narrative theory, , (Downloaded from http://ywcct.oxfordjournals.org/ at University of North on November 22, 2016)

$2:$ "Instead of countering the ideological conception of the cinematic spectator with the notion of real empirical viewers, as so many recent studies in reception theory do, the tropes of the ghost, hauntology, after-effects and deferred meaning make it possible to think of film texts as engaging with the alterity of future audiences as much as current ones. In these terms, cinema, like other arts and technologies, is not bound to the predictability of the future (le future) but the unpredictability of l'avenir, the time to come,"( Downloaded from http://ywcct.oxfordjournals.org/ at University of North on November 22, 2016)

3 "Reviewed in this section are a set of books which, in rather different ways, reanimate the historical approach to cinema: they are not film histories perse, but they each take us further into the rich ground where history, culture, and the philosophic imagination meet, and
} 
far established models stemming from psychoanalysis, cultural studies, reception theory or cognitivism. It is exactly this emphasis on the move-away from, among others, the reception theory that proves to us to what extent the reception theory application in film studies used to be generally accepted.

Ernest Mathijs dealt with specific reception in his work 'Bad reputations: the reception of 'trash' cinema'. Mathijs believes that marketing and reception contexts, both historical and topical, play a crucial role in determining the public meaning of a film text and believes that the discourse of its reception actually starts long before it is received (which can be considered the epoch's horizon of expectations (author's comment). Such considerations are fully justified on the reception theory.

Further, similar considerations are discussed in the work 'Film history terminable and interminable: recovering the past in reception studies' by Barbara Klinger in which she states ${ }^{2}$ that 'Reception studies scholars almost exclusively come to terms with a film's meaning by considering the impact that its original conditions had on its social significance.' Klinger points out the presence of contextual analyses which hope to reveal the impact of discursive and social situations on the film, and they examine a network of relationships between a film and filmic element with intertextual fields such as censorship, exhibition practices, star publicity and reviews, and the dominant or alternative ideologies of society at a particular time, that is, reception theories again.

As we can see, most of these works and studies (which represent only a small part of the researched sample which also has similar characteristics) quite competently apply the legality of the theory of literary reception to the medium of film, but in doing so, they mostly concentrate on the historical reception of the film. This approach, of course, cannot be applicable for this research on contemporary synchronic level, since the mobile reception of films is a new concept in the ways of showing and reception of the film and it is not possible in the diachronic analysis.

\section{Redefining of Film Reception Legality}

The film is as a mass medium, but with the existing and very present artistic component (in the paper we will not insist on the division of the film into artistic and commercial film, because the debate about it would take us in a completely different direction and would greatly complicate the planned development guidelines relating to redefining of exclusively reception terms) much more suitable for questioning of different horizons of expectations, which, we believe, have changed more than, for example literature, which still represents a largely individual experience. The film is, therefore, chosen as the primary investigated medium although the studied theories focused primarily on literature or on the written text. But the film, with its literary template in the basis, represents a kind of upgrade to the literature which is more approachable to the

inform the appreciation of the cinema./.../,One of the tendencies in this rethinking is a move away from the models that have historically dominated theories of spectatorship, whether these emerge from psychoanalysis, cultural studies, reception theory, or cognitivism." (Downloaded from http://ywcct.oxfordjournals.org/ at University of North on November 22, 2016)

1 "marketing and reception contexts, both historical and topical, play a crucial role in determining the public meaning of a film text and explaining the creation of reputation, hypes and controversy./.../ the pursuit of information from the time of the film'sinception (which is an obvious influence on the film's further development) and its significance for the ways in which the film is eventually presented and received raise the theoretical problem that the discourse of its reception actually starts long before it is received./.../This provides a view of the complex pattern of influences and opinions that makes up a film's reception. (Downloaded from http://screen.oxfordjournals.org/ at University of North on November 22, 2016)

2 "the object of literary analysis from the text to the intertext - the network of discourses, social institutions, and historical conditions surrounding a work - they helped inspire the development of historical reception studies in film. Those engaged in reception studies typically examine a network of relationships between a film or filmic element (such as a star), adjacent intertextual fields such as censorship, exhibition practices, star publicity and reviews, and the dominant or alternative ideologies of society at a particular time. Such contextual analysis hopes to reveal the intimate impact of discursive and social situations on cinematic meaning, while elaborating the particularities of cinema's existence under different historical regimes from the silent era to the present. /.../ On occasion, reception studies focused on the industry fail to raise the question of how the industrial context connects to surrounding social and historical processes. /.../ Reception studies scholars almost exclusively come to terms with a film's meaning by considering the impact that its original conditions had on its social significance. (Downloaded from http://screen.oxfordjournals.org/ at University of North on November $22,2016)$ 
nowadays audience than the book itself. In a culture of the visual and virtual ${ }^{12}$, which today more than ever is emphasized by the visual quality of all-pervasive Internet, the audience has even more pronounced demands and assumed changes must be more clearly shown in the visual media ${ }^{3}$, such as film, which is therefore, with the necessary respect for the obvious differences, fully adequate to show the reception transformations.

In the scientific literature this approach is not new, but his opponents appear frequently. Thus, for example, the professor Milivoj Solar in his 'Lectures on bad taste' points out that 'At the same time, the image accompanied by speech radically narrows the scope of imagination. The very fact that the image prevails over the speech in advance cancels what theorists call places of uncertainty. What you get on the screen does not give you anything to suggest further imagining and thinking, but you get a concrete form product that is in the consequences exclusively confined to affirmative suggestion' (Solar, 2004: 22.). If we accept such a position, and partly we have to agree with him, one more fundamental concept of the reception theory requires redefinition, and that is (according to $\left.\right|_{\text {sser }} ^{4}$ ) the function of empty spaces. However, the coming of age of a new generation of film audiences, which is used to receive non-linear content, selecting by interest and scrolling content that they do not read, but scan, they fill empty places that were not selected in a completely new way. Because they are so used to it and have learned to access the media in that way, their particular approach will be applied to the chronological, non-interactive media by inserting empty spaces into sequences that did not predict such course of actions by extending their meaning and creating no more mass media hypnotic effect, but individual experience. In that way, the film will be a medium that will most satisfy their still existing artistic demands that social networks and television cannot meet. In such an approach conative structure of the film ${ }^{5}$ is more prominent, so it is understandable that the film has a big impact on social issues and particularly on the actions of an individual.

By transferring the film through this relatively inadequate equipment, the quality of the recorded film will be much lower than on the cinema screen for which it was originally recorded. On the mostly small screens (let us even take into account cell phone screens) you simply cannot discern what would be seen in the cinema or even on television. Therefore, there are new empty spaces that the viewer has to complement by his/her imagination. This leads to an almost absurd situation that in fact the poor quality of the film reproduction leads to its greater artistic value! The filmmakers will probably never agree with this thesis (we are not sure if we ourselves can agree with it), but it certainly gives us food for thought.

When we talk about new ways/techniques of receiving/watching the film, we must be aware that the horizons of expectations have fundamentally changed. The very term horizon of expectations can thereby remain unchanged from the original Jauss's definition ${ }^{6}$, or the one by Charles Robert Mandelkov? ${ }^{7}$.

\footnotetext{
1 : „The roots of longing for the virtual world are fixed in permanent Western belief in the sight as the most noble organ and the sensual metaphor for expansion of understanding. That belief helped in creating a space for the imaging virtual world of visual language that promises 'transcendence' and emotionality in images, which has been denied for us until this day because of our material incarnation." (Hillis, 2001: 107.)

${ }_{2}$ „New virtual terms are not just fashion, they are a new perspective on things /.../ These terms tell us about deep changes which the contemporary culture is going through and the role that literature and art have in these changes /....." (Oraić Tolić, 2005: 209.)

${ }^{3}$ The importance of the visual language was also noted by Umberto Eco in his study Sounds and images: 'Democratic civilization will be saved only if the language of the picture sets the challenge to critical thinking, rather than a call for hypnosis.' (Eco, 2005: 179.) ${ }^{4}$ Wolfgang Iser deals more thoroughly with the relationship of the text and the reader, as well as the concept of uncertainty. He believes that if we accept that uncertainty represents elementary prerequisite for action, then the question arises about what its expansion, especially in modern literature, actually means. It certainly changes the relationship between the text and the reader. The more the text loses of its uncertainty, the more the reader gets involved in the completion of its possible intentions. The amount of uncertainty in literary prose, and perhaps in the literature in general, is the most important element in the inclusion of the reader in the text (according to Iser, 1978: 94. and 112.)

${ }^{5}$ According to $\mathrm{W}$. Iser, conative structure of the text is the most important element of including the reader into the text.

${ }^{6}$ The biggest news in Jauss's theory is the introduction of the concept of 'horizon of expectations', which provoked much controversy. Jauss considers that the new text evokes for the reader (listener) the horizon of expectations and those rules of the game which he knows from previous texts and which are now being repaired, altered or only reproduced. The reader may notice a new work in the more narrow horizon of his literary expectations, as well as in the wider horizon of his life experience (according to Jauss, 1978: 45,47.) ${ }^{7}$ Karl Robert Mandelkov also discussed a horizon of expectations, stating that there are a number of different horizons of expectations. He wondered whether it was justified to talk about one horizon of expectations, or is the historical reality such that one work is continuously received in the mirror of different horizons of expectations depending on non-concurrency and non-uniformity of simultaneous holders of action? Already at the level of historical synchrony at least three different foils of expectations can be
} 
Moving the film on the medium of the Internet (although thus the Pandora's box of copyright relating to almost all Internet content has been opened), the film has received another form of its appearance, or another transmission medium to the audience. In doing so, the individual reception is further influenced by social reception, but to a lesser extent because the online film viewer has the opportunity to, without the mediation of cinemas and distributors, choose a film on his own, but the selection will still probably be influenced by the film's advertising campaigns. However, low-budget films become available as well which owe their promotion almost exclusively to positive evaluation of the audience that evaluates and/or shares them with other users. Therefore, an individual viewer takes more than an active role in promoting a particular film that, in the above case, does not have to invest abundant resources in advertising campaign. Also, film criticism is reduced here to amateur comments, which are short and mostly unskilled, but the audience trusts them much more than the 'professional' ones whose authors, as the impression has been created, are often members of particular film interest lobbies. The possibility of evaluating, sharing, commenting and discussing the film through the Internet and social networks gives the film added value and meets the need of the audience for the immediacy and interactivity that is expected of all content on the Internet, and also of the film, which, in itself, does not have this feature. A new layer of expectations horizon appears here, and that is the horizon of device expectations. As the audience responded to the need that any content posted online must have an interactive content as well, the film industry has done the same. It already started with films on DVD, where they quickly responded to the online media's third request, and that is connectivity, and they offered a choice of content related to the film; shots from the filming, unlisted parts of the final film, uncensored parts, interviews with the cast and director, music videos with film music, link to an online store offering T-shirts, scarves, cups, figurines ... with characters and situations from the film which opens the possibility of creating additional indirect financial gain.

The fourth feature of online media, and that is archivism, will also come into focus while searching the films so that, after watching a particular film, the device 'itself' (using the 'cookies') offers similar films under the assumed affinity; director, actor, genre ... from the vast archive of films on the Internet.

The expectations of the audience, which is understandable, experience the most complete change. Since the film is received through computers, laptops and mobile phones (smartphones), the audience expects of the film similar stimuli and similar forms of presence as in other contents they receive through their gadgets. These expectations will also be linked to the resolution, design, photography and film syntax, and expectations will be extended to the form of film's narrative as well. Since a large number of viewers were raised on computer games, they will look for similar stimuli in the film, remaining less empathic for the fate of the characters, but also for the violence in the film, which, indeed, appears less brutal on a small screen than on the big screen. And although it seems fundamentally different, the requirements of the audience have been changing for centuries in similar direction: 'We do not state that the audience is more corrupt than before: it just has more experienced nerves, so it needs rougher and cruder stimulations.' (Ujević, 2004: 200.)

Hereby, we come to another postulate of the reception theory, and this is a film audience. V. Žmegač wrote about the phenomenon of the audience, but of the literary audience, declaring: 'From the methodological point of view it is necessary to draw attention to the lack which is often accompanied by theoretical considerations about the reception (for example Jauss's considerations), and this lack is reflected in the generalized, abstract understanding of 'literary audience'/.../The audience, as we conclude, is definable as a sociological and also literary-aesthetic category: in the literary process the reader is economic factor, and partly a selective one, but he is one of the unknown heroes of literature, anonymous or present, elusive figure whom the author either gives in and pleases or throws down a challenge to him.' (Žmegač, 1976: 71- 73.) With the film audience this is even more prominent since one entire, very profitable industry, that is the film industry, is based precisely on the whims of the audience and it is very important, from the standpoint of profit, to assess what film audiences 'love' and what they do not like. Of course, just as the case is with literature, but also with the news media, this pandering to audiences usually goes towards loosening and adjustment and reduction of challenges, rather than its referral that is still present in the non-commercial art film.

Talking of the industry in the context of the reception, and it is more than necessary with the film, it is impossible to bypass the categories of production and consumption that are woven into the critique of political economy of Karl Marx ${ }^{1}$. Besides

conceptually distinguished that determine the process of reception and influence it. Mandelkov called these foils the epoch's horizons of expectations, acts expectations and expectations of the author (according to Mandelkov, 1978: 120.)

1 Introduction to the Critique of Political Economy was created in 1857 and first published in the journal Die Neue Zeit, 1903, in its unfinished form. 
the categories of production and consumption ${ }^{1}$, Marx also mentions the way of consumption which proved to be a special and new in the case of the film reception through ICT. Another theorist of receptions refers to MarX, and that is Manfred Naumann: 'If we do not forget its 'substantial difference', then 'the production of art' is nothing more than just a 'special form' of production, and hence the same provisions apply to it as the ones 'that apply to production in general.' (Nauman, 1978: 138). When we talk about the film industry, even the reception via the Internet, we cannot disagree with these two theorists from (before) the last century, even though, at first glance, it seems impossible and bizarre, primarily because of the exceptional time delay, but also all the connotations associated with Marx, especially in this region.

\section{Conclusion}

The darting changes brought by the progress of information and communication technologies, which caused a reversal in the understanding and functioning of all forms of human communication, the biggest change (with naturally the way or technology of receiving) has been experienced exactly by the audience. The assumed hypothesis at the beginning of this paper that the change of such an important factor, such as the audience, placed the whole reception theory in imbalance has been demonstrated in terms of the necessity of redefining certain settings.

The paper redefined notions of contemporary audience and different horizons of expectations, and a new horizon of expectations has been established, and that is the horizon of device expectations. Also, we have redefined the conative function i.e. the empty spaces function, individual and social reception of the film, while the theory of production relations in the case of the production of art has been applied to the film industry. The paper applies to the film received through social networks requirements of all characteristics of new media, which is also a novelty in scientific thinking. All contemporary changes were compared with root settings of reception theory, rather than with contemporary interpretations.

\section{Bibliography}

[1] Barbara Klinger. Film history terminable and interminable: recovering the past in reception studies. Screen1997. ( Downloaded from http://ywcct.oxfordjournals.org/ at University of North on November 22, 2016)

[2] Dubravka Oraić Tolić, 2005: Muška moderna i ženska postmoderna, Rođenje virtualne kulture. Zagreb, Naklada Ljevak

[3] Ernest Mathijs. Bad reputations: the reception of'trash' cinema. Screen. 2005. ( Downloaded from http://ywcct.oxfordjournals.org/ at University of North on November 22, 2016)

[4] Hans Robert Jauss, 1978: Estetika recepcije, Izbor studija. Beograd, Nolit

[5] Hans Robert Jauss, 1978: Književna istorija kao izazov nauci o književnosti, Teorija recepcije u nauci o književnosti. Beograd, Nolit

[6] Karl Marx, 1969.Uvod u kritiku političke ekonomije, Beograd, Prosveta

[7] Karl Robert Mandelkov, 1978: Problemi istorije delovanja, Teorija recepcije u nauci o književnosti. Beograd, Nolit

[8] Ken Hillis, 2001: Kulture interneta, Geografija oka: Tehnologije virtualne stvarnosti. Zagreb, Naklada Jesenski i Turk, Hrvatsko sociološko društvo

[9] Lisa Trahair. Film Theory. Years Work Crit Cult Theory. 2007. ( Downloaded from http://ywcct.oxfordjournals.org/ at University of North on November 22, 2016)

[10] Lisabeth During and Deborah Levitt. Film Theory. Years Work Crit Cult Theory.2010. ( Downloaded from http://ywcct.oxfordjournals.org/ at University of North on November 22, 2016)

\footnotetext{
${ }_{1}^{1}$ Production produces consumption in that it creates a material, an object of consumption, and through the object, which is always just that particular object, it creates a way of spending and creating the need for spending, spending incentive, 'the ability for consumption', i.e. in so far as creating an entity for the subject. Consumption also produces production to the extent that it creates real product; as opposed to natural object, the object created by the man only becomes a real product when it is confirmed in consumption and consumption creates the need for new production (according to Marx, 1969: 205-241)
} 
[11] Manfred Nauman, 1978. Književnost i problemi njene recepcije Teorija recepcije u nauci o književnosti. Beograd, Nolit,

[12] Milivoj Solar- 2004. Predavanja o lošem ukusu, Obrana estetičkog uma. Zagreb, Politička kultura

[13] Online sources:

[14] Thomas Albrecht and Celine Surprenant. Narrative. Years Work Crit Cult Theory.2008. (Downloaded from http://ywcct.oxfordjournals.org/ at University of North on November 22, 2016)

[15] Tin Ujević, 2004: Opojnost uma. Zagreb, Školska knjiga

[16] Umberto Eco, 2005: Zvuci i slike. Zagreb, Europski glasnik, Godište X, br. 10.

[17] Viktor Žmegač, 1976: Književno stvaralaštvo i povijest društva. Zagreb, Sveučilišna naklada Liber

[18] Wolfgang Iser, 1978: Apelativna struktura tekstova, Teorija recepcije u nauci o književnosti. Beograd, Nolit 